\title{
Graduate real estate education: integrating the industry
}

\author{
by \\ Lisa Chambers, Ichambers@sandiego.edu, University of San Diego \\ Jen Holm, jholm@sandiego.edu, University of Minnesota \\ Elaine Worzala, eworzal@clemson.edu, Clemson University
}

\begin{abstract}
In 2005, a pilot study of graduate real estate programs examined the coalescence of industry and the classroom in 14 well-recognized programs from around the world (Chambers and Worzala, 2005). This study expands the 2005 results in order to include all graduate programs listed in the tenth edition of ULI's Directory of Real Estate Development and Related Education Programs (2005) as well as graduate real estate programs certified by the Royal Institution of Chartered Surveyors (RICS) ${ }^{1}$.

As in the original study, we surveyed academics within the various programs to determine how the graduate programs are enhanced by directly incorporating real estate industry professionals into the curriculum as well as how the programs provide external opportunities for graduate students to interact with business professionals.

The results of this study analyse existing strategies and we hope to suggest criteria for "best practices" to apply in graduate real estate programs around the world. Strategies examined include the use of project-based courses, mentoring and shadowing programs, speaker series, internships, networking events, executive-in-residence programs, career fairs, guest lecturers, alumni associations and field trips.

In addition, some questions focus on the respondents' perceptions of the most effective strategies in foster student/industry interaction. We also queried the academics about alternative performance measurements and assessment tools that could be used in the future to rank real estate graduate educational programs.
\end{abstract}

$1 \quad$ One school offering a Master of Science in Real Estate program (New York University) was not listed in the directory but was included in the survey. 


\section{Introduction/ Motivation of the Study}

Many educators and researchers have examined the gap between the industry and academia in terms of real estate research. Numerous practitioners have commented on how the two groups do not speak to each other or work with each other very well [1], and others have spent their careers trying to bridge this very important gap. See Graaskamp [2, 3, 4, 5 and 6] and Delisle [7] for examples of how the Wisconsin program has integrated industry into real estate education. In addition, see Worzala [8] for additional insights on ways to bridge the gap between academia and industry.

This study is focused on examining how graduate real estate programs around the world bring the outside industry into the real estate classroom by providing opportunities for real estate students to interact with real estate professionals. ${ }^{2}$

\section{Literature Review}

The relevant literature generally follow two underlying themes encompassing the direction needed to be taken to improve the relationship between real estate education and the industry. In one stream of work, the researchers focus on improving the education process and the fundamental approach to working with graduate students. In the other stream, the researchers focus on improving the knowledge base of students as well as the direct connectivity between the business community and institutions of higher education. In addition, other researchers have examined the number and types of real estate programs around the world. For example, see Schulte [10] for a description of the real estate education programs offered in 37 countries or regions around the world and Lizieri and Baum [11] for a study focused on the European university-based real estate programs.

According to Gibler [12], the fundamental knowledge base necessary for a real estate graduate includes writing skills and teamwork. In her research, she finds that these areas have been under-taught and in some cases even ignored by educational institutions that teach real estate. Her paper explores the use of Writing Across the Curriculum (WAC) in a real estate investments course and finds that by requiring the students to write in the genre, style and tone that they will use in their professional lives in course projects they obtain the confidence and the skills necessary to effectively communicate in their real estate careers after graduation. Wolverton and Butler [13] also examine the delivery of real estate curriculum and the various skill sets of real estate students. In their study, they detail how they have reorganized their undergraduate real estate program to enhance the student's

2 One recent study, Wong et al. [9] examines the quality of student applicants. They analyze the fluctuations of student quality in relation to Hong Kong real estate prices. They confirm a positive relationship between the quality of students and the market performance. They suggest that programs should diversify their student body and accept students from areas that have countercycle real estate market performances. 
learning experience by incorporating more active learning processes and integrating a team based approach to solving real estate problems.

Schulte et. al. [14] focus their study on the internationalization of real estate education. Like our study, these researchers used a survey technique and tried to establish the status quo as well as the latest developments in regards to the internationalization of real estate curriculum. Respondents reported the degree of internationalization of close to 70 real estate programs for 27 countries. For the most part, the study focused on the existence of international real estate as a topic in the curriculum rather than on how the material is delivered and whether or not the programs include the use of real estate professionals and experiential learning. However, a few questions focused on the international cooperation between universities that includes exchange and study abroad programs for students. They found that less then one-third of the program respondents offered exchange programs and one-third of the programs offered study aboard programs. Only $16 \%$ of the polled institutions offered a joint degree/diploma with an international institution.

From the standpoint of improving the connectivity between the academics and the business community, the demand or needs of employers should be tied in more closely with the educational programs that create the supply of able minded and skilled graduates. Numerous authors have written about the importance of this connectivity in real estate education. Butler, Guntermann and Wolverton [15] find the need for the industry connectivity to be an essential factor in facilitating graduate- level real estate education. Anderson, Loviscek, and Webb [16] take a similar approach and argue for the use of proble $\mathrm{m}$-based learning techniques to enhance the problem solving and critical thinking skills of students. They highlight the importance of including problem based assignments that encompass a range of real world scenarios in to the classroom and find that the long term comprehension of the material by the students is enhanced when this technique is applied. Hardin [17] comments on how interactions between the employers and the educational systems often leads to more workplace skill sets entering the real estate curriculum.

Manning and Roulac [18] review the changing nature of business education and suggest several ways for real estate faculty to enhance existing educational programs. They emphasize how the addition of "real-world active student learning experiences" (i.e. internships, projects, etc.) greatly enhance a student's ability to apply their skills in the workplace environment. In addition, they advocate for business schools to take on a more problem focused environment where students and the faculty work closely as apprentices to professionals. In these "third level" courses, students take on complex real world problems with an industry professional as well as business school faculty. These types of courses require students to pull from multiple courses of study and to draw on interdisciplinary knowledge. In addition, they provide a situation where the students can develop "their mental agility, integrity, trustworthiness, concern for others and tolerance for ambiguity" which are all important for successful real estate professionals (pg. 35).

Several recent studies have looked at business school education in the United States. Bennis and O'Toole [19] recently found that the faculty of the top business schools have been moving away from providing the necessary tools present-day employees need in the 
workforce. Some researcher have even accused business schools of having "physics-envy" that entails hypothetical theorization rather than a hands- on, concise, method of approaching business education.

A recent study completed by the Urban Land Institute [20] concludes that there is not enough communication between business and educational programs in the real estate industry. Therefore, new graduates are ill-prepared for the challenges they face in the business environment. This study questions the need for specialized masters programs and suggests what employers really need are students who are able to communicate, think critically and solve problems. Many of the techniques used by the survey respondents in this study are ways for students to get involved with the industry so that they are better able to serve their future employers.

Weinstein [21] takes a look at top ranked U.S. real estate graduate programs and interviewed the leaders of each program. She notes that one of the significant traits of some of the more highly ranked programs is the high degree of industry relationships within the leadership of the program that are made available to the students in the programs. In a later study, Weinstein [22] used the learning experiences of 33 real estate CEOs to ascertain what should be included in leadership programs at the graduate level. She concluded with 12 innovations that should be included in a real estate program if it is striving to create real estate leaders. One third of the innovations include the direct involvement of industry professionals including providing opportunities for students to network outside the classroom, assigning mentors from the real estate profession, guest speakers in the classrooms and internships.

Galuppo and Worzala [23] surveyed employers in the real estate community. They looked at employees who had an MS degree and those that did not. They found that the survey respondents highlighted the importance of direct industry relationships for graduate real estate programs. In addition, they looked very favorably on including reat world, live projects in a graduate real estate educational program. These authors argue that the range of skills that MSRE students are exposed to, if they focus their education only on the real estate asset class, is more expansive than a traditional graduate business program. In addition, they hypothesize that MSRE programs should provide students with a high volume of industry speakers, mentors, and guest lecturers.

Although numerous researchers have written about the importance of bringing industry professionals into the real estate graduate level classroom, no one has examined the extent to which existing faculty have developed programs that facilitate the interaction. This study examines how graduate programs around the world have tried to bring the outside into the classroom and to develop practices for integrating industry with real estate programs. The results have provided some insights and ideas for the academic community as to how to bridge the gap between real estate academics and real estate professionals.

\section{Methodology and Results}

This paper presents the results of a survey that was completed in May 2006. We originally sent the survey to 133 graduate real estate programs around the world. The graduate real 
estate programs we surveyed were either listed in the tenth edition of the Urban Land Institute's Directory of Real Estate Development and Related Education Programs [24] or they are certified programs that were provided by the Royal Institution of Chartered Surveyors (RICS).

Thirty-four programs from around the world responded to our survey, resulting in a $25 \%$ response rate. Figure 1 lists the 13 US and 21 International institutions who responded. In the original sample, there were 41 US-based schools but some of them did not have graduate programs. The sample dropped down to 36 US based schools. We got responses from 13 of the US based institutions which gives us a $36 \%$ response rate. Like the US based schools, we started out with 108 international universities in the original database that was reduced to 94 due to lack of a graduate program or faulty email addresses. We received 21 completed surveys back for a response rate of $22 \%$ for that cohort.

Figure 1: List of Universities that Responded to the Survey

\begin{tabular}{|c|c|}
\hline United States (13) & International (21) \\
\hline Clemson University & University of Aberdeen (UK) \\
\hline Cleveland State University & Universidad de Alicante (Spain) \\
\hline Columbia University & City University, Cass Business School (UK) \\
\hline University of Denver & Dublin Institute of Technology (UK) \\
\hline Florida State University & ESSEC (France) \\
\hline Indiana University & European Business School (Germany) \\
\hline Johns Hopkins University & Leeds Metropolitan University (UK) \\
\hline University of Michigan & Napier University (UK) \\
\hline University of North Carolina - Charlotte & National University of Singapore \\
\hline New York University & Nelson Mandela Metropolitan University (S.Africa) \\
\hline University of San Diego & University of New Brunswick (Canada) \\
\hline University of St. Thomas & RMIT University (Australia) \\
\hline \multirow[t]{9}{*}{ University of Wisconsin - Madison } & Royal Agricultural College (UK) \\
\hline & York University (Canada) \\
\hline & Sheffield Hallam University (UK) \\
\hline & Universidad Politecnica de Valencia (Spain) \\
\hline & Universitat Leipzig (Germany) \\
\hline & University of Antwerp Management School (Belgium) \\
\hline & University of Reading (UK) \\
\hline & University of Sheffield (UK) \\
\hline & University of Westminster (UK) \\
\hline
\end{tabular}


The intent of the study was to show some of the most commonly and most effective practices used to bring the real estate industry into the classroom and to determine if there is any significant difference between programs in the US and international programs. In addition, we highlight some relatively unique practices that have been set up at some schools may be useful for other programs to more actively engage the real estate professional in the classroom Finally, responses provide some useful insight into what attributes or performance measurements could be used to judge the success of a graduate real estate education program.

The survey was designed in 'Survey Monkey'3 and program directors were sent to the survey via an email link. One reminder email was also sent. The questions were designed for mostly a simple yes/no response or a multiple answer selection. There were also some open-ended questions intended to gather more detailed information on the practices used. The questions were grouped together into six categories: Demographics, Classroom Activity, Internship and Career Placement, Activities External to the Classroom, Industry Support Structure, and Performance Measurement. The Performance Measurement section asked respondents to rank the importance of measurement tools on a scale from one to five. This will help us to assess, in the future, how graduate real estate education programs could be ranked in the future.

\section{Programs' focus}

Among the selected programs, $61.8 \%$ have a full real estate focus. The various titles of these Real Estate programs could be: Master of Science in Real Estate (MSRE), Master of Science in

Real Estate Development (MSRED), Master in Real Estate (MRE), Master of Science (MSc) and Master in Real Estate and Consruction Management (MSRECM).

In addition, $26.5 \%$ have a MBA with real estate focus (more than four real estate courses) and $11.8 \%$ of them have a MBA with real estate emphasis (1-4 real estate courses).

Finally, over a third (35.3) of the respondents chose "other" (Planning Masters (MUPDD), $\mathrm{PhD}$, Masters in Architecture and graduate certificate programs.)

\section{Programs' length and load}

As shown in Figure 2, among the schools which have a specialized degree in real estate $60 \%$ have a one year program, 30\% have a two year program and 10\% have an 18 month program. 
Figure 2 Programs' length

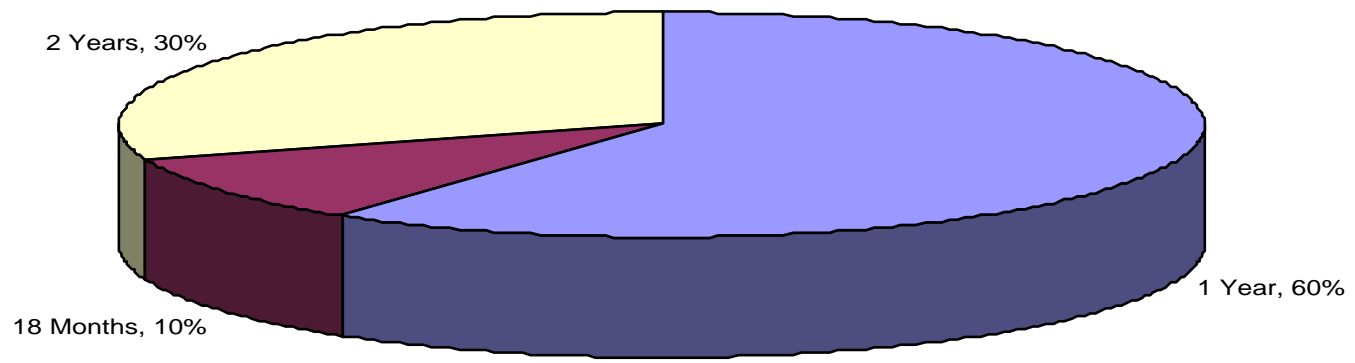

Figure 3 illustrates that 35\% programs are offered full-time, 26\% part-time and 39\% offering both a full-time and part-time option. Of the schools with an MBA with a real estate focus, three quarters of them (78\%) offered the degree on both a full time and part time basis, with no school offering only part time. None of the MBA programs with a real estate emphasis offered their program on a part time program, but half $(50 \%)$ of them offered their program only on a full time basis, with the other half of the programs offering the program both full and part-time programs.

Figure 3: Programs loads

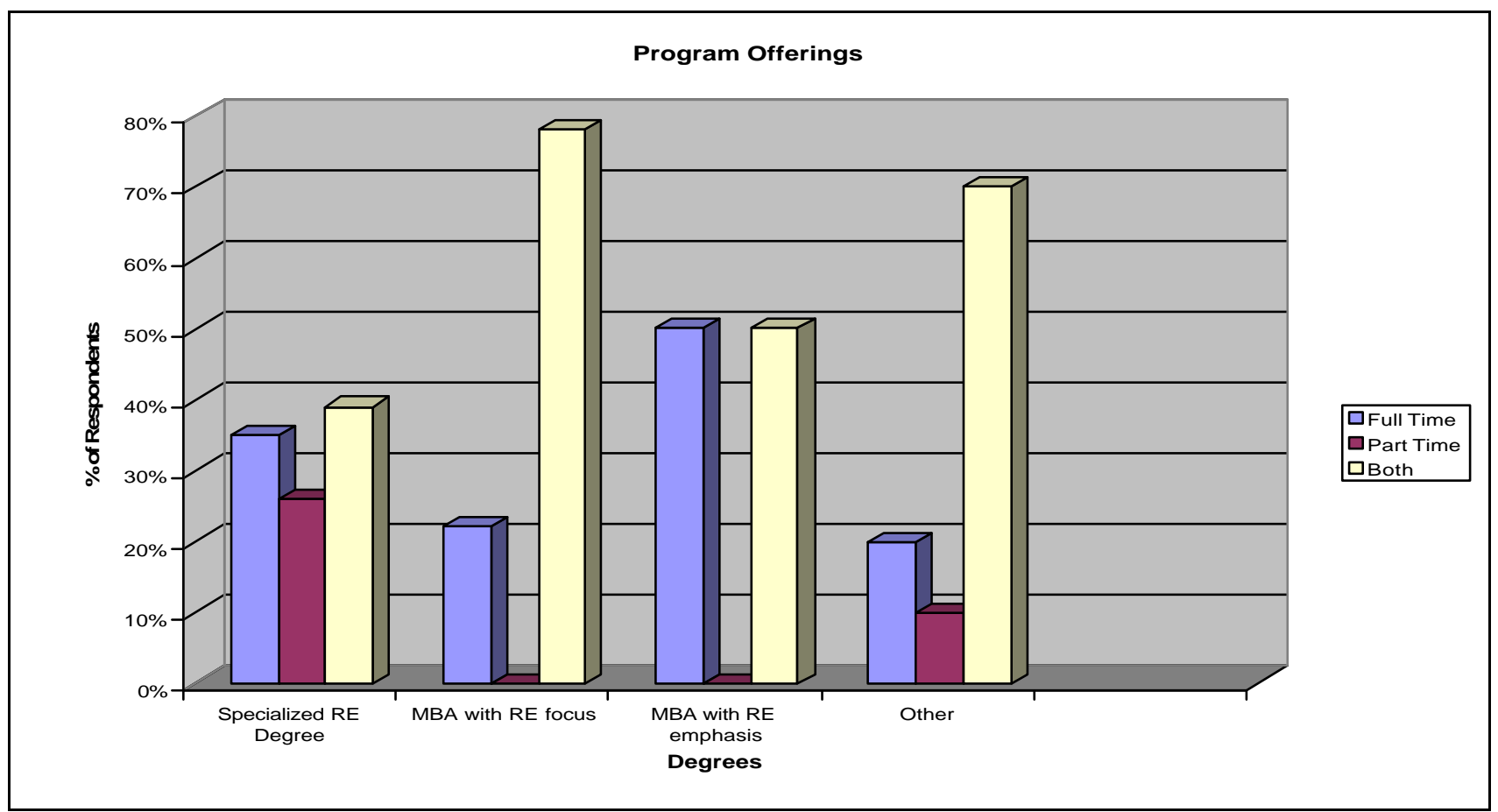




\section{Classroom activity}

The second series of questions dealt with the activities used by graduate real estate programs to bring the industry into the classroom. Of all the programs surveyed, $94 \%$ used guest lecturers in their classrooms and there was no difference when the sample was divided between respondents US and international institutions. Formal real estate speaker series are implemented by almost two-thirds of the schools surveyed, again with no significant difference between US and international schools. When asked where the speakers are drawn from, most respondents (90\%) said they pull speakers from their local communities, $70 \%$ said they have speakers from another part of their country and slightly over half said they include international speakers in their classrooms. Here, there is a slight but not substantial difference between U.S. and international schools.

Figure 4 Where invited speakers came from

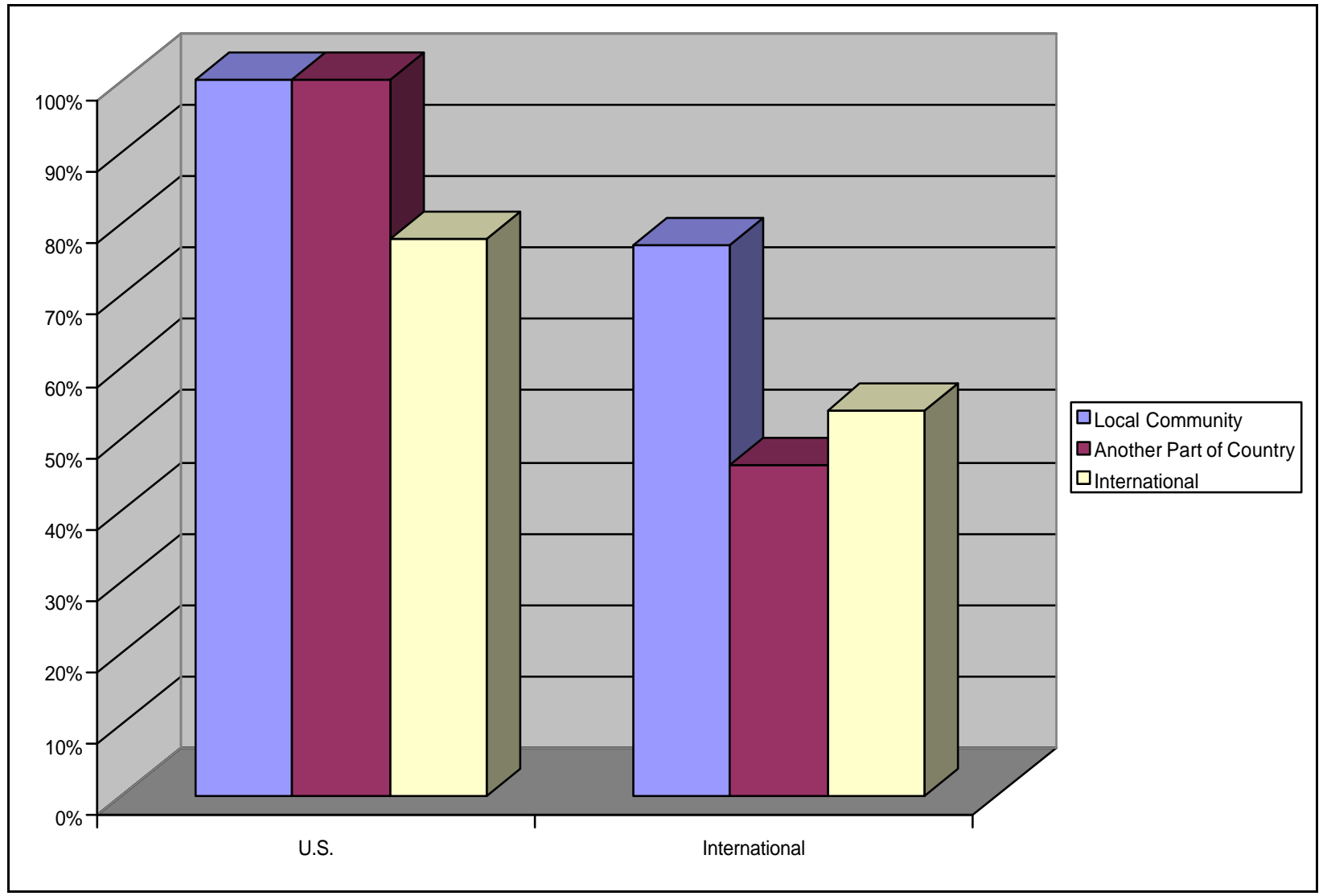

Slightly under one-third of the respondents (31\%) indicated that they had an executive in residence programs where industry professionals were brought on campus. When asked how the professionals were used, $78 \%$ used them were used as guest lecturers, $45 \%$ used them to teach courses in the curriculum and slightly under one- half $(45 \%)$ used them to mentor students on a formal basis.

In the last ten years, active or experiential learning has become an important pedagogical component of graduate education. The use of live projects in the coursework, where students 
are teamed up with an industry professional, is one way to directly expose the students to the industry. The projects allow the allow the student to "get their hands dirty" while they learn the theory and concepts of a particular course of study. An additional benefit is that students develop a working relationship with real estate professionals before they graduate and enter a real estate career.

Most real estate programs rely on some form of experiential learning. Most us "live projects" as a part of the course requirements ( $42 \%$ reported using live projects in their courses). This percentage was significantly higher $(69 \%)$ in U.S. schools than in international programs (24\%). The most common courses which the schools used "live projects" was Development, (Offered in $57 \%$ of the programs) and Valuation and Feasibility (50\%). The other courses that relied on experential learning: Business Strategy, Independent Study, Internships, Capstone Course and Final Projects.

Field Trips are another way to get the students directly involved with the industry. The majority of the schools ( $85 \%$ ) indicated that they used field trips and many of the programs had them set up as required for the student's course of study. Three quarters of the respondents indicated that they had required local field trips while slightly over one-third of the programs required out of city and/or international field trips. Optional field trips were less common with $35 \%$ indicating they had local field trips, $28 \%$ out of city and $24 \%$ offering optional international field trips.

\section{External Activities}

The survey contained other questions focused on the different strategies used by real estate programs in order to foster interactions with real estate professionals. It appears that one of the most common techniques was to hosted informal networking events (in three quarter of the programs). Another popular approach is to host information sessions with real estate companies while almost $60 \%$ of the respondents indicated that they had their students participate in industry sponsored competitions. Slightly over half of the programs sponsor their own industry conferences while slightly below half of the respondents provide direct mentoring or shadowing experiences for their students to meet and work with industry professionals.

We also wanted to get a sense for how different programs were set up organizationally to involve the industry in their programs. The most common structure was to have an advisory board made up of real estate professionals. Over $70 \%$ of the respondents indicated that they had established such as organization. Many of the programs also had created either a real estate club (56\%) and/or a real estate alumni association while half of the respondents had also created a real estate center.

\section{I nternships and Career Placement}

Career placement is often cited as an important criteria for ranking the quality of a graduate real estate program. Therefore, we also queried the program directors about their involvement with helping their students find jobs both as interns during their graduate 
programs as well as permanent career placement upon graduation. In addition, we wanted to know how common internships with formal academic ties were for the various programs responding to the survey. The most common internship offered, by $53 \%$ of the respondents, was a paid internship with no academic credit. Slightly over one-third of the respondents offered unpaid internships with no academic credit. Internships for credit were a much less common alternative with close to one-fourth offered as paid job opportunities and slightly under one-fifth offered as unpaid internships for credit. When it comes to full- time career placement, only $35 \%$ of the respondents indicated that they offered career services for fulltime employment.

We also asked the respondents how they handled career placement for their graduate real estate students as this would provide direct connection with the industry as they search for potential employees. Over half of the programs indicated that they provided career placement services within their real estate group while $40 \%$ indicated that they partnered with the university career placement. In addition, close to one-third of the respondents indicated that they partnered with a career placement office within their school. Only $6 \%$ of the respondents indicated that they relied exclusively on either the university or the school placement offices. This provides evidence that the majority of the real estate programs are taking an active role and allocating resources to this important part of the education process. When asked how new internship/career opportunities were discovered, the vast majority $(87 \%)$ indicated the industry contacted the programs while two-thirds of the programs indicated that they actively solicited job opportunities from the industry. Finally, $36 \%$ of the respondents indicated that they hosted a career fair on their campus.

We were also curious to see how the students were informed about job opportunities. The most common method was to regularly post openings to the students through emails (64\%) while $40 \%$ of the programs posted the current openings on the website and/or in hard copy form on a bulletin board. The least common alternative was to have a job book in the department office which is not surprising since it provides limited access to the students. The success rate of finding employment for the graduate real estate student was quite high for the programs responding to the study. Over half of the schools (55\%) indicated that between 91-100\% of their graduates were gainfully employed within 3 months of graduation. Thirty percent of the schools indicated that $76-90 \%$ of their students had jobs within 3 months. There were, however, a few schools (10\%) that were not as successful and had only placed $10-25 \%$ of their students within this time period.

A large majority of the programs had an advisory board but the use of a real estate club, alumni associations and/or a center were not as common. Career placement was not offered by every school but over $50 \%$ of the programs did allocate resources within their own unit to help the students find jobs. It appears that not every one has embraced the online approach to seek candidates (only $40 \%$ posting the job opportunities are on line). Finally, only onethird of the programs indicated that they hosted career fairs. The final questions focused on the performance measurement of the programs and it is clear that the industry perception of the graduates was clearly the number one measurement. 


\section{Performance Measurement}

As the importance of accreditation and formal assessment of academic programs grows within the academic community, ways to measure the success of the graduate real estate programs will become increasingly important. Therefore, we used a Likert scale and asked respondents to rate the importance of several alternative ways to measure the success of their graduate programs. Panel A of Figure 5 details the mean responses to the various categories with the industry perception of the real estate graduates clearly being the most important criteria for measuring the success of the programs. This alternative had a mean rating of 4.70 a 5 point Likert scale with a 5 rating indicating the performance measurement was very important.

The second most important criteria was alumni feedback with a 4.27 mean rating while quality of the applicants was ranked as the third most important It was somewhat surprising, but the lowest mean rating was for the salaries of the graduates as that is probably one of the more important criteria for students choosing between alternative programs. When the data is split between US based schools and international schools, the important criteria shift as detailed in Panel B and C of Exhibit X. For the US, Alumni success and feedback is the number one criteria for measuring the success of the program with a mean rating of 4.86 followed by the perception of the industry (4.77) and quality of the applicant. The least important criteria for the measurement of success for the US based programs was external reviews/accreditation. On the other hand, the International schools indicated the industry perception was very important (4.66) followed by external reviews/accreditation. In this case, the lowest mean rating went to the salaries of the graduates although the number of applicants as well as alumni success/feedback also had relatively low mean ratings (3.8 and 4.1 , respectively).

Figure : Graduate Real Estate Success Measurement

\begin{tabular}{|lcccccc|}
\hline & $\begin{array}{c}\text { Overall } \\
\text { Mean Rating* }\end{array}$ & $\begin{array}{c}\text { Overall } \\
\text { Ranking }\end{array}$ & $\begin{array}{c}\text { US } \\
\text { Mean }\end{array}$ & $\begin{array}{c}\text { US } \\
\text { Ranking }\end{array}$ & $\begin{array}{c}\text { International } \\
\text { Mean }\end{array}$ & $\begin{array}{c}\text { International } \\
\text { Ranking }\end{array}$ \\
\hline Industry perception of graduates & 4.7 & 1 & 4.77 & 2 & 4.65 & 1 \\
Alumni feedback/success & 4.39 & 2 & 4.85 & 1 & 4.1 & 5 \\
Quality of the applicants & 4.27 & 3 & 4.31 & 4 & 4.25 & 3 \\
External reviews/accreditation & 4.24 & 4 & 3.77 & 7 & 4.55 & 2 \\
Placement of students & 4.21 & 5 & 4.38 & 3 & 4.1 & 4 \\
Number of applications & 3.85 & 6 & 3.92 & 5 & 3.8 & 6 \\
Salaries of graduates & 3.55 & 7 & 3.85 & 6 & 3.35 & 7 \\
\hline * Mean response is based on a Likert Scale where $5=$ Very Important and 1 = Very Unimportant & \\
\hline
\end{tabular}

The difference between the US-based and international programs is likely due to the very important role that external reviews play for international programs while in the US based 
programs external reviews and/or accreditation specific to real estate programs is nonexistent.

In addition, the tradition of staying in touch with and cultivating alumni appears to be stronger in the US based schools than it is in the international programs. It is evident from these results that it will be important to take into account these differences if we are to establish assessment techniques to measure the success of the various graduate real estate programs as well as to try to compare across alternative programs and potentially rank the quality of graduate real estate programs. This is an area of future research as the numbers of programs available grows and students and employers have more opportunities to choose between graduate real estate programs around the world.

\section{Conclusions}

This paper details the results of a survey designed to determine how the industry is integrated in to 34 graduate real estate programs. The majority of the respondents had specialized real estate degrees and most of them were one year programs. The most common activities found in the classroom included guest lecturers and formal speaker series. Live projects were also relatively common with the development course as the most likely course to include this experiential learning technique. Required local field trips were also very common while some of the schools offered both required and optional longer field trips either in another city and in one-third of the programs there was a required international field trip. On the external side, informal networking events and informational sessions with real estate companies were relatively popular amongst the respondents while $60 \%$ of the programs had students participating in industry sponsored competitions such as ULI or the European Challenge. This means that getting the industry involved in graduate real estate education is essential as we try to bridge the gap between industry and academics involved in graduate real estate education. 


\section{References}

[1] Souza, L. A. 2000. Academic and Applied Real Estate Research: "As Two Worlds Collide" or "As Two Worlds Divide"? J ournal of Real Estate Portfolio Management 6 (1): 97-100.

[2] Graaskamp, J. A. 1974. Redefining the Role of University Education in Real Estate and Urban Land Economics. The Real Estate Appraiser. March/April. Reprinted in Graaskamp on Real Estate. Edited by Stephen Jarchow. 1991. 40-50.

[3] Graaskamp, J. A. 1977. An Approach to Real Estate Finance Education by Analogy to Risk Management Principles. Real Estate Issues. Summer 53-70.

[4] Graaskamp, J. A. 1977. The Failure of the Universities to Teach Real Estate Process as an Interdisciplinary Art Form, Distinguished Lecture Series. Centre for Real Estate and Urban Economic Studies, The University of Connecticut. Reprinted in Graaskamp on Real Estate. Edited by Stephen Jarchow. 1991. 51- 67.

[5] Graaskamp, J. A. 1978. University Contributions to Real Estate and Land Use Enterprise Management Education. The Graaskamp Collection. CD Rom Published by Wisconsin Real Estate Alumni Association. 1998. I.C.23.

[6] Graaskamp, J. A. 1983-4. Overcoming the Obstacles to Education. Journal of Real Estate Education. Winter Edition. Reprinted in Graaskamp on Real Estate. Edited by Stephen Jarchow. 1991. 68-72.

[7] Delisle, J. R. 2000. Graaskamp: A Holistic Perspective. Essays in Honor of James A. Graaskamp: Ten Years After. Edited by James R. DeLisle and Elaine M. Worzala. Chapter 3: 51- 58

[8] Worzala, E. M. 2002. Bridging the Practical/Academic Divide in Real Estate. Pacific Rim Property Research Journal 8 (1): 3-14.

[9] Wong, S.K, Wong, K.C, Chau K.W, Yiu, C.Y, Ho, D.C.W. 2008. Does Student Quality Fluctuate With Real Estate Prices? Journal of Real Estate Practice and Education, 11 (2)

[10] Schulte, K.W. 2000. Real Estate Education Throughout the World: Past, Present and Future. Research Issues in Real Estate. Volume 7.

[11] Lizieri, C. and Baum, A. 2002. Real Estate Education in Europe. Report for the Urban Land Institute.

[12] Gibler, K. M. 2001. Applying Writing Across the Curriculum to a Real Estate Investment Course. Journal of Real Estate Practice and Education 4 (1): 42- 53.

[13] Wolverton, M. and J. Q. Butler. 1997. Denying Traditional Senses: Lessons About Programme Change. Teaching in Higher Education 2 (3): 295- 313.

[14] Schulte, K.W., Schulte-Daxbok, G., Breidenback, M., and Wiffler, M. 2005. Internationalization of Real Estate Education, ERES Conference: Dublin, I reland.

[15] Butler, J., Guntermann, K. L., and Wolverton, M. 1998. Integrating the Real Estate Curriculum. Journal of Real Estate Practice and Education 1 (1): 51-66. 
[16] Anderson, R. I., Loviscek, A.L., and Webb, J. R. 2000. Problem based Learning in Real Estate Education. Journal of Real Estate Practice and Education 3 (1): 36- 41

[17] Hardin III, W. G. 2001. Practical Experience, Expectations, Hiring, Promotion and Tenure: A Real Estate Perspective. Journal of Real Estate Practice and Education 30 (2): 17- 34.

[18] Manning, C. and Roulac, S. 2001. Where Can Real Estate Faculty Add the Most Value at Universities in the Future? J ournal of Real Estate Practice and Education 4 (1): 18-39.

[19] Bennis, W.G and J. O'Toole. May 2005. How Business Schools Lost Their Way. Harvard Business Review 83 (5): 96.

[20] Urban Land Institute. 2003. Human Capital Survey. The 2003 Equinox Report.

[21] Weinstein, M. 2002. Examination of Top Real Estate MBA Programs: Implications for Improving Education for Practitioners. ARES Conference: Naples, FL.

[22] Weinstein, M. 2004. An Investigation of CEOs' Learning Experiences: Implications for Leadership Programs in Universities. ARES Conference: Captiva Island, FL.

[23] Galuppo, L. A. and Worzala, E. M. 2004. A Study into the Important Elements of a Masters Degree in Real Estate. Journal of Real Estate Practice and Education 7 (1): 2542.

[24] Urban Land Institute. Directory of Real Estate Development and Related Education Programs, 10 ${ }^{\text {th }}$ Edition. Washington DC. 2005. 



